\title{
PROFESSIONAL CAREER, SUCCESS AND HIGHER EDUCATION IN THE VALUE SYSTEM OF REGIONAL UNIVERSITY STUDENTS (BASED ON THE SOCIOLOGICAL SURVEY MATERIALS)
}

\author{
Oksana V. Vasilenko ${ }^{1}$, Tatiana S. Ignateva ${ }^{2 \star}$, Marina S. Sapriko ${ }^{3}$, Natalya I. Ivanova ${ }^{4}$, \\ Natalia B. Malinina ${ }^{5}$, Anna V. Motorova ${ }^{6}$ \\ ${ }^{1}$ Assoc. Prof., Chuvash State University, RUSSIA, vasilenkoksana@rambler.ru \\ ${ }^{2}$ Assoc. Prof., Chuvash State University, RUSSIA, tatius67@yandex.ru \\ ${ }^{3}$ Assoc. Prof., Chuvash State University, RUSSIA, sapriko.m@mail.ru \\ ${ }^{4}$ Assoc. Prof., Chuvash State University, RUSSIA, orchestra@yandex.ru \\ ${ }^{5}$ Senior Lecturer, Chuvash State University, RUSSIA, cherrru84@mail.ru \\ ${ }^{6}$ Senior Lecturer, Chuvash State University, RUSSIA, ann-21-rusanna@ya.ru
}

\begin{abstract}
The relevance of studying the ideas of the regional university students about professional success, career, and the role of education is due to the fact that the choice of professional journey, building a future career in the educational process among modern students remains rather low. At the same time, the problem of personnel outflow in the regions of Russia is regularly discussed at all levels of government bodies and in the scientific community.
\end{abstract}

The purpose of this article is to study the ideas of modern students of a regional university about professional success, career and education.

The authors suggest that the research data can help clarify the ideas about the value orientations of modern student youth, study various aspects related to the career of young people, and contribute to the construction of career strategies for young people.

Since it is young people who play the main role in the professional reproduction of society, the study of the career strategies of young people can make it possible to develop career guidance work at school and university.

The given article considers some questions of the survey conducted in November - December 2020. 111 students of humanities field, 65 - natural science field and 80 - technical field were interviewed. Selection criteria were faculty (humanitarian and technical) and course (3-4 courses of bachelor's degree). The research was carried out by the method of group questioning in classrooms.

The survey involved young men (41.8\%) and girls (58.2\%), aged 18-19 (10.9\%); $20-21$ years old (82.8\%); 22 years and older $-6.3 \%$ of respondents.

During the survey, when answering the question "Do you combine study and work?" $41.8 \%$ of respondents combine study and work, of which $3.5 \%$ work in the profile of their future profession. In the total mass of the surveyed students, the number of working students in the humanities is insignificantly higher in comparison with students of other fields. On the other hand, according to the profile of the future profession, there are quantitatively more technical students. Only $7.8 \%$ believe that work helps to master a specialty. In this 
regard, it is interesting to see that the number of respondents who are dissatisfied with their financial situation coincides in percentage with the number of students who combine work with study. At the same time, the same percentage of respondents says that work interferes with studies.

Next, we were interested in the question of the motives for choosing a profession by students. Having analyzed the motives, we were able to identify those factors that influence the choice of a particular profession by applicants. Overall, the results turned out to be quite predictable: in the first place were good wages, well-being (58.6\%); personal inclinations, abilities (53.5\%); demand in the labor market $(39.1 \%)$ and career opportunities (39.1\%). It is also worth noting that some respondents indicated their ideas about professional activity as a mission in society as a determining factor.

One of the questions asked the respondents to express their opinion about such an instrument of success as having a higher education. $44.1 \%$ of respondents do not consider having higher education a guarantee of success in life. Most likely, there is an understanding in Russian society that other components are also needed to achieve success.

One cannot but agree with a number of researchers who believe that "... a career is perceived by students in a vague and rather broad sense of the word."

This thesis is confirmed by the data of the question "What, in your opinion, is most important in assessing the work?" Income is the most important for respondents when assessing work, this opinion is shared by $69.5 \%$ of respondents, for $51.6 \%$ - good working conditions (safety, cleanliness, convenient schedule, etc.), professional self-realization (the opportunity to show one's abilities, business qualities) $-44.9 \%$, career growth $-41.0 \%$ of students. The choice of respondents is predictable, there are slight differences in the areas of study.

To the open-ended question "What does it mean to be a successful person in the professional environment that you have chosen?" the respondents in their answers put the criterion of achievement in the first place, the most often in their answers were: "recognition, help people, having feedback", "authority", "know your business 100\%"; in second place was the level of wages; further - the position held: "to hold senior positions and do their job perfectly"; then comes the career advancement "to climb well up the career ladder, to have a good command of the relevant competence", and career mobility "permanent business trips abroad".

The study showed that for the respondents, career growth means activities in the form of achievements, for example, "... do their job well" (students of the humanities), "self-realization in the professional sphere" (students of natural sciences), "the opportunity to show their professional skills" (technical students).

So, a modern employer is interested in highly qualified specialists, therefore, today higher educational institutions are faced with the task of professional training of graduates in accordance with those competencies that will not only correspond to the labor market, but even outstrip the requirements of the market.

The conducted survey allows us to investigate the perceptions of respondents at a given time stage. The result of such a study can be designed career guidance work, starting with school, with the involvement of employers of city-forming enterprises and the administration of universities.

Keywords: Student youth, regional university, higher education, professional career, success, value system, sociological survey.

\section{INTRODUCTION}

The relevance of studying the ideas of the regional university students about professional success, career, and the role of education is due to the fact that the choice of professional journey, building a future career in the educational process among modern students remains rather low. At the same time, the problem of personnel outflow in the regions of Russia is regularly discussed at all levels of government bodies and in the scientific community (Trushin, 2019, pp. 16-19).

In research, a career is most often understood as "the sequence of types of work performed by an individual in the course of his working life" (Abercrombie, Hill and Turner, 1997, p. 116).

Therefore, a career as a gradual advancement in the career ladder is accompanied by a change in professional competencies, professional qualifications, an increase in wages and satisfaction with one's 
professional activities. A successful career, according to experts, largely depends on how correctly it was planned. At the heart of such a construct, on the one hand, is the professional characteristic of a person: education, professional knowledge, skills and abilities; on the other hand, the conditions of the social environment of a young person.

Considering the ideas of young people about a career and the factors of its success, it is necessary to highlight the main approaches to understanding this phenomenon that are currently prevailing in science. In the social sciences and humanities, the phenomenon of career is considered from the standpoint of the process, status, value, organizational and individual approaches. In line with the process approach, a career is defined as a way to achieve certain goals and results through personal expression; the status approach as the result of work and social status achieved by the employee; value approach - as a socially significant and valued labor activity of a particular person in society. Within the framework of the organizational approach, a career is interpreted as a career advancement directly related to the modernization of skills, abilities, qualifications and, accordingly, the amount of material remuneration; individual approach - as an individual work path of an employee, the result of which can be expressed both in the professional and in the official form of career growth. In addition, the concept of "career" is used in two senses: narrow and broad. In a narrow sense, a career denotes the process of professionalization, or professional growth associated with a consistent change of professional roles, a gradual ascent of an employee to professionalism, a transition from one level of professionalism to another. In a broad sense, a career includes both professional growth, mastering the levels of professionalism, and the achievement of a certain social status in the job hierarchy, occupation of a certain position, job promotion. Accordingly, the professional and job career of the employee can be considered.

A professional career can reflect a number of significant areas in the process of professionalization of an employee: deepening existing knowledge and expanding competencies within the framework of an already acquired profession; mastering new knowledge, skills and competencies from other (usually related) professional fields, which can be carried out within the framework of additional professional education; mastering a new profession, etc. A job career involves a sequential change by an employee of job positions within the same organization (from lower to higher positions) and can have a structured or unstructured trajectory. Based on this idea of a career, we believe that every young person, joining in labor activity in accordance with his aspirations, can build a career both professionally and in official terms. In our opinion, these two areas of career growth can either be carried out in parallel or not coincide with each other. In other words, for a young person in his work, only his professional growth or only his official promotion can be the main thing, but he can also simultaneously strive to improve his professionalism and to raise his official status.

The purpose of this article is to study the ideas of modern students of a regional university about professional success, career and education.

In foreign and domestic sociology, youth, including students, is a constant object of study.

Professional self-determination of students has been repeatedly considered in the works of such scientists as L.N. Bannikova, Yu.R. Vishnevsky, Ya.V. Didkovskaya (Bannikova, Vishnevsky and Didkovskaya, 2002, P.74-80).

The problems of vocational and labor definition are considered in the studies of S.V. Polutin and V.V. Kozina (Polutin, Kozin, 2016, pp. 192-200).

An assessment of the motivation and work values of young people, trends and features of the work orientations development are given in the studies of E.V. Andrianova, A.N. Tarasova and I.F. Pecherkina (Andrianova, Tarasova and Pecherkina, 2018, pp. 324-343).

The results of the relationship peculiarities study between professional ideas and ideas about success among students of technical and humanitarian specialties, as well as the peculiarities of ideas about the object of activity and work, depending on the dominant model of student success, are given in the article by S.V. Zholudeva and A.O. Antonova (Zholudeva, Antonova, 2014, pp. 110-121).

The study of professional interests, career aspirations of student youth is considered in the works of I.V. Sitnikova (Sitnikova 2019, pp. 61-77.), N.P. Narbut and I.V. Trotsuk (Narbut, Trotsuk, 2014, pp. 143-168.), V.V. Kotovsky (Kotovsky, 2014, pp. 91-96.), V. I. Filonenko, O. S. Mosienko, A. S. Magranova (Filonenko, Mosienko and Magranov, 2020, pp. 283-301) and others.

The authors suggest that the research data can help clarify the ideas about the value orientations of modern student youth, study various aspects related to the career of young people, and contribute to the career 
strategies construction for young people.

Since it is young people who play the main role in the professional reproduction of society, the study of the career strategies of young people can make it possible to develop career guidance work at school and university.

\section{RESULTS AND DISCUSSION}

This article considers some questions of the student survey conducted in November-December 2020. 111 students of the humanitarian training, 65 of the natural sciences training and 80 of the technical training were interviewed. Selection criteria were faculty (humanitarian and technical) and course (3-4 courses of bachelor's degree). The research was carried out by the method of group questioning in classrooms.

The survey involved young men (41.8\%) and girls (58.2\%), aged 18-19 (10.9\%); $20-21$ years old (82.8\%); 22 years and older $-6.3 \%$ of respondents.

During the survey, when answering the question "Do you combine study and work?" $41.8 \%$ of respondents combine study and work, of which $3.5 \%$ work in the profile of their future profession. In the total mass of the surveyed students, the number of working students in the humanities is insignificantly higher in comparison with students of other fields. On the other hand, according to the profile of the future profession, there are quantitatively more technical students. Only $7.8 \%$ believe that work helps to master a specialty.

In this regard, it is interesting to see that the number of respondents who are dissatisfied with their financial situation coincides in percentage with the number of students who combine work with study. At the same time, the same percentage of respondents says that work interferes with studies.

Next, we were interested in the question of the motives for choosing a profession by students.

Table 1. Distribution of answers to the question: "What motives were you guided by when choosing a profession?" (choice of 3-4 answers)

\begin{tabular}{|l|l|c|c|c|c|}
\hline & \multicolumn{1}{|c|}{ Answer options } & $\begin{array}{c}\text { Total } \\
(\%)\end{array}$ & $\begin{array}{c}\text { Humanita- } \\
\text { rian training } \\
(\%)\end{array}$ & $\begin{array}{c}\text { Natural } \\
\text { sciences } \\
\text { training } \\
(\%)\end{array}$ & $\begin{array}{c}\text { Technical } \\
\text { training } \\
(\%)\end{array}$ \\
\hline 1. & $\begin{array}{l}\text { opportunity to benefit } \\
\text { society }\end{array}$ & 23.4 & 19.8 & 30.8 & 22.5 \\
\hline 2. & $\begin{array}{l}\text { demand in the labor } \\
\text { market }\end{array}$ & 39.1 & 26.1 & 35.4 & 60.0 \\
\hline 3. & $\begin{array}{l}\text { personal inclinations, } \\
\text { abilities }\end{array}$ & 53.5 & 63.1 & 47.7 & 45.0 \\
\hline 4. & career opportunities & 39.1 & 50.5 & 29.2 & 31.3 \\
\hline 5. & good salary, well-being & 58.6 & 52.3 & 56.9 & 68,8 \\
\hline 6. & $\begin{array}{l}\text { prestige of the } \\
\text { profession }\end{array}$ & 36.3 & 46.8 & 30.8 & 26.3 \\
\hline 7. & $\begin{array}{l}\text { interesting and } \\
\text { creative work }\end{array}$ & 33.2 & 30.6 & 32.3 & 37.5 \\
\hline 8. & $\begin{array}{l}\text { assumes personal } \\
\text { responsibility }\end{array}$ & 12.9 & 15.3 & 12.3 & 10.0 \\
\hline 9. & other & 2.3 & 1.8 & 1.5 & 3.8 \\
\hline
\end{tabular}

Having analyzed the motives, we were able to identify those factors that influence the choice of a particular profession by applicants. Overall, the results turned out to be quite predictable: in the first place were good 
wages, well-being (58.6\%); personal inclinations, abilities (53.5\%); demand in the labor market (39.1\%) and career opportunities (39.1\%). It is also worth noting that some respondents indicated their ideas about professional activity as a mission in society as a determining factor. The respondents were not limited to one answer option, as a rule, students chose no more than two ready-made options. At the same time, only $2.3 \%$ of the respondents offered their detailed answer to this question.

Answers to the question "What influenced your choice of this profession?" are presented in Table. 2.

Table 2. Distribution of answers to the question: "What influenced your choice of this profession?" (choice of 1-2 answers)

\begin{tabular}{|l|l|c|c|c|c|}
\hline & \multicolumn{1}{|c|}{ Answer options } & $\begin{array}{c}\text { Total } \\
(\%)\end{array}$ & $\begin{array}{c}\text { Humanita- } \\
\text { rian training } \\
(\%)\end{array}$ & $\begin{array}{c}\text { Natural } \\
\text { sciences } \\
\text { training } \\
(\%)\end{array}$ & $\begin{array}{c}\text { Technical } \\
\text { training } \\
(\%)\end{array}$ \\
\hline 1. & $\begin{array}{l}\text { advice from parents, } \\
\text { relatives }\end{array}$ & 30.1 & 33.3 & 29.2 & 26.3 \\
\hline 2. & $\begin{array}{l}\text { opinions and / or } \\
\text { example of friends }\end{array}$ & 9.8 & 9.9 & 9.2 & 10 \\
\hline 3. & positions of teachers & 2.0 & 1.8 & 4.6 & 0 \\
\hline 4. & $\begin{array}{l}\text { the choice is } \\
\text { exclusively } \\
\text { independent }\end{array}$ & 75.4 & 75.7 & 72.3 & 77.5 \\
\hline 5. & other & 1.6 & 1.8 & 0 & 2.5 \\
\hline
\end{tabular}

Having analyzed the data obtained, it is safe to say that a modern applicant independently makes a decision, followed by advice from parents and relatives, opinions of friends.

One of the questions asked the respondents to express their opinion about such an instrument of success as having a higher education.

Table 3. Distribution of answers to the question: "Is higher education a guarantee of success in life for you?"

\begin{tabular}{|l|l|c|c|c|c|}
\hline \multicolumn{1}{|c|}{ Answer options } & $\begin{array}{c}\text { Total } \\
(\%)\end{array}$ & $\begin{array}{c}\text { Humanitari } \\
\text { an training } \\
(\%)\end{array}$ & $\begin{array}{c}\text { Natural } \\
\text { sciences } \\
\text { training } \\
(\%)\end{array}$ & $\begin{array}{c}\text { Technical } \\
\text { training } \\
(\%)\end{array}$ \\
\hline 1. & Yes & 18.4 & 16.2 & 21.5 & 18.8 \\
\hline 2. & No & 44.1 & 45.9 & 43.1 & 42.5 \\
\hline 3. & Hard to say & 37.5 & 37.8 & 35.4 & 38.8 \\
\hline
\end{tabular}

$44.1 \%$ of respondents do not consider having higher education a guarantee of success in life. Most likely, there is an understanding in Russian society that other components are also needed to achieve success. Sociologists note the decline in the value of higher education somewhere after 2010 (Trushin, 2019, pp. 1214.)

3-4 year students have an idea of their future professional activity, since they are undergoing industrial practice, therefore the next question is presented in Table. 4. 
Table 4. Distribution of answers to the question: "Do you see career prospects in your profession?"

\begin{tabular}{|l|l|c|c|c|c|}
\hline \multicolumn{1}{|c|}{ Answer options } & $\begin{array}{c}\text { Total } \\
(\%)\end{array}$ & $\begin{array}{c}\text { Humanita- } \\
\text { rian training } \\
(\%)\end{array}$ & $\begin{array}{c}\text { Natural } \\
\text { sciences } \\
\text { training } \\
(\%)\end{array}$ & $\begin{array}{c}\text { Technical } \\
\text { training } \\
(\%)\end{array}$ \\
\hline 1. & Yes & 55.5 & 52.3 & 49.2 & 65 \\
\hline 2. & No & 8.2 & 11.7 & 4.6 & 6.3 \\
\hline 3. & Do not know & 31.3 & 34.2 & 38.5 & 21.3 \\
\hline 4. & Other & 5.9 & 2.7 & 7.7 & 8.8 \\
\hline
\end{tabular}

$55.5 \%$ see career prospects in the profession. Students studying in a technical direction see more prospects $(65.0 \%)$ than students in other fields.

A number of researchers believe that "studying ideas of a career among students of Russian universities shows that a career is perceived by students in a vague and rather broad sense of the word" (Zhupnik, 2019, pp. 19-27).

This thesis is confirmed by the data of the next question "What, in your opinion, is most important in assessing the work?"

Table 5. Distribution of answers to the question: "What, in your opinion, is most important in assessing work?" (choice of 3-4 answers)

\begin{tabular}{|l|l|c|c|c|c|}
\hline & \multicolumn{1}{|c|}{ Answer options } & $\begin{array}{c}\text { Total } \\
(\%)\end{array}$ & $\begin{array}{c}\text { Humanita- } \\
\text { rian training } \\
(\%)\end{array}$ & $\begin{array}{c}\text { Natural } \\
\text { sciences } \\
\text { training } \\
(\%)\end{array}$ & $\begin{array}{c}\text { Technical } \\
\text { training } \\
(\%)\end{array}$ \\
\hline 1. & $\begin{array}{l}\text { correspondence of } \\
\text { work to education, } \\
\text { profession }\end{array}$ & 22.7 & 18.9 & 33.8 & 18.8 \\
\hline 2. & $\begin{array}{l}\text { opportunity to show } \\
\text { your abilities, } \\
\text { business qualities }\end{array}$ & 44.9 & 51.4 & 35.4 & 43.8 \\
\hline 3. & $\begin{array}{l}\text { guarantees of job } \\
\text { preservation and } \\
\text { salary payments }\end{array}$ & 35.9 & 27.0 & 41.5 & 43.8 \\
\hline 4. & $\begin{array}{l}\text { prestige of work in the } \\
\text { eyes of others }\end{array}$ & 13.3 & 15.3 & 6.2 & 16.3 \\
\hline 5. & high salary or income & 69.5 & 70.3 & 75.4 & 63.8 \\
\hline 6. & $\begin{array}{l}\text { not very difficult, not } \\
\text { tedious work }\end{array}$ & 10.9 & 9.9 & 9.2 & 13.8 \\
\hline 7. & $\begin{array}{l}\text { an opportunity to } \\
\text { make a career }\end{array}$ & 39.8 & 56.5 & 40 & 25 \\
\hline 8 & $\begin{array}{l}\text { availability of various } \\
\text { benefits (vouchers, } \\
\text { loans, etc.) }\end{array}$ & 8.2 & 11.7 & 3.1 & 7.5 \\
\hline
\end{tabular}




\begin{tabular}{|l|l|c|c|c|c|}
\hline 9. & independence in work & 9.0 & 5.4 & 6.2 & 16.3 \\
\hline 10. & $\begin{array}{l}\text { the possibility of } \\
\text { continuous } \\
\text { professional growth, } \\
\text { advanced training }\end{array}$ & 41.0 & 43.2 & 32.3 & 45 \\
\hline 11. & $\begin{array}{l}\text { good working } \\
\text { conditions (safety, } \\
\text { cleanliness, } \\
\text { convenient schedule, } \\
\text { etc.) }\end{array}$ & 51.6 & 54.1 & 49.2 & 50 \\
\hline 12. & $\begin{array}{l}\text { variety, creativity in } \\
\text { work }\end{array}$ & 19.9 & 20.7 & 21.5 & 17.5 \\
\hline 13. & good team & 27.0 & 27.0 & 13.8 & 37.5 \\
\hline 14. & other & 0 & 0 & 0 & 0 \\
\hline
\end{tabular}

Income is the most important for respondents when assessing work, this opinion is shared by $69.5 \%$ of respondents, for $51.6 \%$ - good working conditions (safety, cleanliness, convenient schedule, etc.), professional self-realization (the opportunity to show one's abilities, business qualities) - for $44.9 \%$, and career growth - for $41.0 \%$ of students. The choice of respondents is predictable; there are slight differences in the areas of study.

Modern youth live in the present day without looking far into the future - is that so? (Table 6).

Table 6. Distribution of answers to the question "For what period of time do you make your life plans for the future?"

\begin{tabular}{|l|l|c|c|c|c|}
\hline & \multicolumn{1}{|c|}{ Answer options } & $\begin{array}{c}\text { Total } \\
(\%)\end{array}$ & $\begin{array}{c}\text { Humani- } \\
\text { tarian } \\
\text { training } \\
(\%)\end{array}$ & $\begin{array}{c}\text { Natural } \\
\text { sciences } \\
\text { training } \\
(\%)\end{array}$ & $\begin{array}{c}\text { Technical } \\
\text { training } \\
(\%)\end{array}$ \\
\hline 1. & for the coming days & 12.9 & 9.9 & 16.9 & 13.8 \\
\hline 2. & for a week or two & 9.4 & 10.8 & 10.8 & 6.3 \\
\hline 3. & for months & 26.2 & 24.3 & 27.7 & 27.5 \\
\hline 4. & for years & 34.4 & 39.6 & 32.3 & 28.8 \\
\hline 5. & not making any plans & 14.8 & 13.5 & 10.8 & 20 \\
\hline 6. & other & 3.5 & 2.7 & 4.6 & 3.8 \\
\hline
\end{tabular}

The data obtained indicate that $14.8 \%$ of respondents do not make any plans, that is, they live for today. Short-term plans (for the coming days and for a week or two) - for $22.3 \%$ of the respondents. $34.4 \%$ of respondents make plans for years, such planning is typical primarily for socially active youth.

The effectiveness of an educational institution is also determined by the implementation of the received education in practice (Table 7). 
Table 7. Distribution of answers to the question "What are your plans after getting a profession?" (choice of 1-2-3 answers)

\begin{tabular}{|l|l|c|c|c|c|}
\hline \multicolumn{1}{|c|}{ Answer options } & $\begin{array}{c}\text { Total } \\
(\%)\end{array}$ & $\begin{array}{c}\text { Humani- } \\
\text { tarian } \\
\text { training } \\
(\%)\end{array}$ & $\begin{array}{c}\text { Natural } \\
\text { sciences } \\
\text { training } \\
(\%)\end{array}$ & $\begin{array}{c}\text { Technical } \\
\text { training } \\
(\%)\end{array}$ \\
\hline 1. & $\begin{array}{l}\text { self-realization in your } \\
\text { profession }\end{array}$ & 43.4 & 33.3 & 50.8 & 51.3 \\
\hline 2. & $\begin{array}{l}\text { retraining to another } \\
\text { profession }\end{array}$ & 15.6 & 18.9 & 10.8 & 15 \\
\hline 3. & $\begin{array}{l}\text { work in any } \\
\text { profession }\end{array}$ & 12.9 & 13.5 & 15.4 & 10 \\
\hline 4. & $\begin{array}{l}\text { start your own } \\
\text { business }\end{array}$ & 34.8 & 38.7 & 32.3 & 31.3 \\
\hline 5. & continue education & 28.1 & 28.8 & 32.3 & 23.8 \\
\hline 6. & $\begin{array}{l}\text { I don't know yet, I } \\
\text { need to look around }\end{array}$ & 24.2 & 29.7 & 24.6 & 16.3 \\
\hline 7. & other & 2.3 & 1.8 & 3.1 & 2.5 \\
\hline
\end{tabular}

It can also be noted that only $15.6 \%$ of respondents are interested in changing the field of activity. This phenomenon can also be explained by the fact that while studying at a university, undergoing industrial practice, students may be aware of their wrong choice.

In the course of the research carried out among students, it was revealed that $28.1 \%$ of them intend to continue their education, since the master's degree allows one to obtain competencies of a broader profile. $43.4 \%$ respondents plan to work in their specialty.

To the open-ended question "What does it mean to be a successful person in the professional environment that you have chosen?" the respondents in their answers put the criterion of achievement in the first place, the most often in their answers was: "recognition, help people, having feedback", "authority", "know your business $100 \%$ "; in the second place was the level of wages; next was the position held: "to hold senior positions and do their job perfectly", "to rise to the position of deputy a minister in any area"; then was a career advancement: "to climb well up the career ladder, to have a good command of the relevant competence", and last - the career mobility, e.g. "permanent business trips abroad".

The study showed that for the respondents, career growth means activities in the form of achievements, for example, "... do their job well" (students of the humanities), "self-realization in the professional sphere" (students of the natural sciences), "the opportunity to show their professional skills" (technical students).

And the last question of the questionnaire was devoted to the value system of the respondents.

Table 8. Distribution of answers to the question: "What, in your opinion, makes a person happy?" (choice of 1-2-3 answers)

\begin{tabular}{|l|l|c|c|c|c|}
\hline & \multicolumn{1}{|c|}{ Answer options } & $\begin{array}{c}\text { Total } \\
(\%)\end{array}$ & $\begin{array}{c}\text { Humani- } \\
\text { tarian } \\
\text { training } \\
(\%)\end{array}$ & $\begin{array}{c}\text { Natural } \\
\text { sciences } \\
\text { training } \\
(\%)\end{array}$ & $\begin{array}{c}\text { Technical } \\
\text { training } \\
(\%)\end{array}$ \\
\hline 1. & interesting job & 46.1 & 42.3 & 49.2 & 48.8 \\
\hline 2. & high salary, income & 42.6 & 40.5 & 43.1 & 45 \\
\hline
\end{tabular}




\begin{tabular}{|l|l|c|c|c|c|}
\hline 3. & family & 65.6 & 74.8 & 56.9 & 60 \\
\hline 4. & love & 46.5 & 55 & 46.2 & 35.0 \\
\hline 5. & friendship & 23.8 & 23.4 & 21.5 & 26.3 \\
\hline 6. & $\begin{array}{l}\text { career, professional } \\
\text { achievements }\end{array}$ & 18.4 & 25.2 & 10.8 & 15 \\
\hline 7. & $\begin{array}{l}\text { social status, respect } \\
\text { for people }\end{array}$ & 16.0 & 18 & 15.4 & 13.8 \\
\hline 8. & health & 48 & 46.8 & 46.2 & 51.3 \\
\hline 9. & $\begin{array}{l}\text { peace of mind, clear } \\
\text { conscience }\end{array}$ & 31.6 & 22.5 & 38.5 & 38.3 \\
\hline 10. & other & 2.3 & 1.8 & 3.1 & 2.5 \\
\hline
\end{tabular}

The research results show that the most important value in the life of boys and girls is the family $(65.6 \%)$. In second place is health (48\%), and in third place is love (46.5\%), interesting work (46.1\%), high salary, income (42.6\%). Career ranks next to last. In last place is social status and respect for people.

So, it should be noted that young people mostly choose their future profession independently. The main motive is a stable income, higher education is no longer a guarantee of success in life and less than a third of the surveyed graduates intend to continue their education (28.1\%).

One third of students (34.4\%) plans their life for years ahead. $43.4 \%$ of respondents plan to link their activities with their chosen profession.

Half of the respondents (55.5\%) note the possibility of career prospects.

The amount of income, working conditions and professional self-realization are priorities when evaluating a job. It should be noted that the family remains the most important value in the life of boys and girls $(65.6 \%)$.

\section{CONCLUSION}

A modern employer is interested in highly qualified specialists, therefore today higher educational institutions are faced with the task of professional training of graduates in accordance with those competencies that will not only correspond to the labor market, but also even outstrip the requirements of the market.

The survey allows us to study the perceptions of the respondents at this time stage, the differences in the areas of study at the university. The result of such a study can be designed vocational guidance work, starting with school, with the involvement of employers of city-forming enterprises and the administration of universities.

In our opinion, starting from school, it is necessary to create conditions for the professional selfdetermination of a student. In turn, students, receiving fundamental knowledge in higher education, should clearly understand that without the skills of critical thinking, digital communication and planning a professional career, it would be difficult to realize themselves professionally.

\section{REFERENCE LIST}

Abercrombie, N., Hill, S. and Turner B.S. (1997). Career. Sociological Dictionary.

Andrianova, E. V. (2018). Motives and labor values of youth: paradoxes of development. Monitoring of public opinion: Economic and social changes, 3.

Bannikova, L.N., Vishnevsky, Yu. R. and Didkovskaya, Ya. V. (2020). Study of the problems of professional self-determination of students in the Sverdlovsk region. University management, 2 (13). 
Filonenko, V. I., Mosienko, O.S. and Magranov, A. S. (2020). Representations of student youth about professional choice (Based on the materials of interregional sociological research 2006-2016). Education Issues, 1.

Kotovsky, V.V. 2014. Socio-psychological characteristics of students' ideas about professional success. Applied legal psychology, 2.

Narbut, N.P., Trotsuk, I.V. (2014). Life plans of Russian student youth: gender and other differences in assessments of their own prospects in the labor market. Bulletin of RUDN University, 3.

Polutin, S.V. (2016). Professional-labor definition of youth in the region. Regionology, 4. http://elibrary.ru/item.asp?id=27526793

Sitnikova, I.V. (2019). Professional plans and strategies for the employment of modern students. Bulletin of PNRPU. Socio-economic sciences, 4.

Trushin, A. (2019). Abroad will not help. Ogonyok, 45.

Trushin, A. (2019).Superfluous higher education. Ogonyok, 32.

Zholudeva, S.V., Antonova, A.O. (2014). The relationship of professional ideas and ideas about success among students of different specialties. Professional ideas: collection of scientific papers of the Internet conference "The value of ideas in education and professional development of the individual".

Zhupnik, O.N. (2019). Career in the system of values of modern student youth. Scientific notes of the V. I. Vernadsky Crimean Federal University Sociology. Pedagogy. Psychology, 5 (71) 